\title{
Doing Good Together: Competition Law and the Political Legitimacy of Interfirm Cooperation
}

\author{
Rutger Claassen \\ Anna Gerbrandy \\ Utrecht University
}

\begin{abstract}
Demands have been growing upon firms to take actions in the interests of workers, the environment, local communities, and others. Firms sometimes have felt they could best discharge such responsibilities by cooperating with other firms. This, however, is suspect from the point of view of a purely economic interpretation of competition law, since interfirm agreements may raise prices and thus lower welfare for consumers. Should competition law remain focused on competition enhancing economic welfare, or be reformed to allow for acts of cooperation that are socially beneficial? To answer this question, the article provides a philosophical reevaluation of the deep-seated view that firms are merely private actors. It argues that demands of political legitimacy should also be addressed at firms cooperating together, and that standard views of democratic accountability should be broadened, introducing a model of delegated, sequential decision making which allows regulatory agencies and parliaments to control interfirm agreements.
\end{abstract}

KEY WORDS: competition law, political legitimacy, democratic accountability, interfirm agreements

ccording to a standard understanding of the marketplace, firms need to compete.
Competition is essential to have the price mechanism do its work, ensuring free
markets to allocate resources efficiently and work in the interests of all. Competition
between firms cannot be taken for granted, and therefore an important part of the
regulatory framework surrounding markets concerns competition (or antitrust) law.
The rules of competition law guard against abuses of market power and the rise of
cartels, thus ensuring effective competition. At the same time, over the last decades,
demands have been growing upon firms to take action in the interests of workers,
the environment, local communities, and others (i.e., to take their 'corporate social
responsibility'). In some cases, firms have felt they could best discharge such respon-
sibilities by cooperating with other firms to ensure sustainable production processes
or to set minimum standards for workers' safety. These instances of cooperation,
where firms have concluded agreements with other firms ('doing good together') are
suspect from the point of view of a purely economic interpretation of competition
law, since they may raise prices and thus lower welfare for consumers. If competition
law follows such an economic perspective, then interfirm agreements will have to
be prohibited. Should competition law remain focused on competition enhancing 
economic welfare, or should it be reformed to allow for acts of cooperation which are socially beneficial?

This is the eminently practical question which drives this article. There are established legal and economic arguments to debate how much space competition law can and should give to interfirm agreements to protect noneconomic interests (which we and others have treated elsewhere). In this article, however, we will focus on the implications of this issue for moral/political philosophy, in particular for democratic theory. To give an answer to the practical question requires, we will attempt to show, a reevaluation of the deep-seated view that firms are merely private actors, to which no requirements of public legitimacy and democratic accountability can be addressed. The aim of this article is to introduce the reader to the legal debate about the purposes of competition law and the legal provisions and cases exemplifying the cooperation/ competition conundrum, and then to offer an analysis of the philosophical dimensions of the tension between demands of cooperation and demands of competition, with which competition law has to deal. With respect to the practical question, we will make the case that competition law can legitimately be broadened to take noneconomic interests into account. We show how this position requires a reformulation of standard views about legitimacy and accountability within democratic theory. Thus, the interest of the article is not only in philosophically justifying an answer to a practical question vexing competition lawyers. The practical issue points us to the need to reconsider clashing views of legitimacy and democracy within democratic theory itself.

The first two sections introduce the legal dimensions of the cooperation/competition problem. First, we introduce the normative debate about the proper goals of competition law. Throughout its evolution over the last centuries, there has always been debate about these goals, and for the specific problem of this article it is important to understand this background. Second, we focus on the recent debate about cooperative actions in competition law. Using the example of European competition law, we show how the currently dominant interpretations of competition law's purposes cannot make room for the protection of so-called noneconomic interests by firms cooperating with each other. This raises the practical question whether competition law should make room for such cooperative practices.

The next three sections analyze this problem in terms of democratic theory. We first set the problem in the context of the broader debate about the public/private distinction, and then argue for two main positions in democratic theory. The first issue is about the scope of demands of political legitimacy. Against the standard view that only public institutions should be held democratically accountable, we argue that demands of public legitimacy should also be addressed at firms cooperating together, given the coercive impact on society of such agreements. The second issue is about the way in which such accountability is organized. Here we argue in favour of broadening standard views of democratic accountability by introducing a model of delegated, sequential decision making which allows regulatory agencies and parliaments to control interfirm agreements.

Finally, we return to the legal practice and discuss two important practical objections which have been raised by those who are critical of broadening competition law's purposes, arguing this might give the wrong incentives to firms and will be legally infeasibile 
to adjudicate. We argue these objections provide important reasons for careful scrutiny but are no reason to cancel the innovations in competition law needed on principle.

\section{THE PURPOSES OF COMPETITION LAW: AN OVERVIEW}

The debate on the purpose of competition law (or antitrust law, as it is called in the US) is a continuous one. From the adoption of the Sherman Act in the US in 1890, to the incorporation of the competition law provisions in the treaty establishing the (then) European Economic Community in 1957, it continues through the current spread of competition rules throughout the world. This is not a settled debate. However, it is important, as the interpretation of the competition rules-which are generally not linguistically difficult and drafted as relatively short legal prohibitions-depends in large part on the established raison d'être of competition rules.

The introduction of the Sherman Act was aimed at breaking up the trusts that existed at the end of the nineteenth century in the US - the joined forces of huge railroad companies and monopolistic oil companies able to extort high prices as competition was (growingly) absent. The explicit goal was breaking the power of these monoliths, as Senator Sherman indicated: "If we will not endure a king as a political power, we should not endure a king over the production, transportation, and sale of any of the necessaries of life."' Courts generally held that the Sherman Act should be understood as a charter of economic liberty, aimed at preserving free and unfettered competition. This view was based in general economic theory, from which it followed that competition would yield the best allocation. Despite this economic motive, the general idea in the early days of antitrust remained that it primarily fulfilled a political function: preventing concentrations of private power, and thereby upholding "democratic political and social institutions" (Brock 1983). These notions were not very well defined, however, and strongly voiced criticism against this vagueness gained ground. This legal criticism from the Chicago School of Economics, with an active group of scholars from the new field of law and economics was primarily aimed at the Harvard School of Law, where competition law was seen as an instrument for an active government to shape the structure of markets. The law and economics scholars, in contrast, held a strong conviction that not the structure of the market, but having an unfettered market mechanism would lead to optimal market outcomes and greatest economic welfare. They proposed that the market mechanism would not need intervention by the government and that any disturbances (market imperfections) would generally correct themselves. This changed the focus of competition law from being aimed at actively protecting market structures to a competition law that would interfere only if there was strong economic evidence of a (lasting) detrimental effect to economic welfare (Bork 1978).

The European Union's debate on the goals of competition law shows variations on this theme. Here, Germany's school of ordoliberalism played a pivotal role. Whereas American anti-trust has roots in common law-which is built incrementally from case to case-from its inception, this influential legal-economic school started from the basis of principles. One of these principles, to be implemented in post-war Germany, is the idea that just as one would need a political constitution to prevent a buildup of power in the hands of a few to guarantee individual (political) 
freedom, one would need an economic constitution to protect against the buildup of economic power to guarantee individual economic freedom (Gerber 2001). Strong, independently enforced competition rules are necessary, aimed at protecting this individual sphere of economic actions against encroaching economic power. The formative years of European competition law were heavily influenced by this line of reasoning. In addition, the EU's (originally the EEC's) competition regime also was (and is) aimed at establishing the 'internal market': the single, integrated, market sphere where goods, services, capital, and workers might freely move. This goal of competition law is quite specific to the EU and might lead to outcomes in cases that would be idiosyncratic in the US regime, for example. However, from the eighties onwards, the Chicago-school approach became more influential. As a result, the European competition regime as enforced by the European Commission ('the Commission'), underwent a change in the direction of 'economization.' Its single goal, the Commission now consistently puts forward, is to protect consumer welfare. It is not clear, however, what the European Court of Justice ('the Court') makes of this, as it has-at the very least-leaned towards a multi-goal interpretation of the legal provisions. ${ }^{2}$

This is the state of play in which the current debate takes place. On the one hand there is a fairly dominant economics-based approach to competition law. This is based on the general premise that the market mechanism leads to optimal outcomes and greatest economic efficiencies. Though there are differences as to which exact legal standard is to be applied, the general goal of competition law, in this line of reasoning, is fairly straightforward: to prohibit those behaviors that have a negative effect on (consumer) welfare. On the other hand, however, there are voices criticizing this predominantly economic paradigm. They point towards the basis of competition law in the principles of economic freedom, dispersion of power, the protection of small and medium sized enterprises, and 'fairness' or 'equity' as either also playing a role, or even as replacing the welfarist approach (Parret 2010, Lianos 2013). The legal literature has both a descriptive character, for example, mapping the position of the Court against the position of the Commission, and a normative character, discussing what the aim of competition law ought to be. ${ }^{3}$

\section{COMPETITION LAW AND NON-ECONOMIC INTERESTS}

Competition law provisions normally consist of three major parts: a prohibition on agreements (cartels), a check on the abuse of market power (dominant positions), and a control of mergers. We focus exclusively on agreements in this article. ${ }^{4}$ Taking European competition law as our example: article 101 of the Treaty on the Functioning of the EU (TFEU) prohibits "all agreements between undertakings, decisions by associations of undertakings and concerted practices which may affect trade between Member States and which have as their object or effect the prevention, restriction or distortion of competition within the common market" (art. 101 par. 1 TFEU). ${ }^{5}$ The article mentions several specific practices, such as price fixing and limiting production, as examples of such anticompetitive behaviour. As pointed out above, within the currently dominant interpretation embraced by the Commission charged with the enforcement of European competition law, the ultimate aim of this 
prohibition is to maximize the welfare of consumers (the so-called consumer welfare approach). ${ }^{6}$ Consumers may be disadvantaged by agreements between firms in terms of facing higher prices, a restricted supply of goods, or foregone innovations. When agreements lead to such market failures, the optimizing features of the general equilibrium framework (the systematization of Adam Smith's invisible hand) do not obtain and there is a prima facie economic rationale for state intervention. ${ }^{7}$ Thus, in this frame, competition law serves to enhance consumer welfare by protecting against the negative consequences of market power.

This criterion does not favour prohibitions in all cases. There may be cases in which the consumer welfare approach permits interfirm agreements, even though the agreement has a negative consumer welfare effect. Competition law systems normally offer space for this. In the European context, this is enshrined in an exception clause stating that the prohibition of paragraph 1 may be overruled where an agreement "contributes to improving the production or distribution of goods or to promoting technical or economic progress, while allowing consumers a fair share of the resulting benefit" (art. 101 par. 3 TFEU). ${ }^{8}$ This is the case, for example, in many vertical distribution agreements, such as selective distribution or exclusive dealing; it is also the case in some research and development agreements and intellectual property licensing agreements which might lead to a better distribution network, high and continued quality of service, protection of brand exclusivity, or innovative or improved products or services. Thus, in competition cases, a balancing act is needed between the prohibition and this exception, between negative effects and positive effects on consumer welfare, to decide which course of action would maximize consumer welfare in the case at hand. All of this remains within the consumer welfare approach, since the formulation of the exception points to the efficiency gains sometimes to be had from allowing agreements, as long as these trickle down to a sufficient extent (a 'fair share') to consumers. This has led to a lively practice of firms claiming, and courts and competition authorities deciding, that a given interfirm agreement is or is not justified on grounds of consumer welfare. In this practice, the claims of both sides remain within the bounds of the economic approach to competition law.

Recently, however, more agreements have surfaced in which firms claim the applicability of the exception clause on the basis of what is often called in this debate 'noneconomic interests' (somewhat unfortunately, since 'economic' here refers to consumer interests/welfare only), such as environmental, labour, and public health standards. ${ }^{9}$ This raises the issue central to this article. Some examples of different types of noneconomic interests may be helpful.

First, consider labour standards and workers' protection. In the wake of the 2013 Rana Plaza disaster (the collapse of a clothing factory in Bangladesh), the Fair Wear Foundation took the initiative to improve workers' safety and workers' compensation (a 'living wage'). This involved leading apparel firms who have their garments made in Bengali factories. These firms agree to a small uplift on the price paid to the factory for a finished product, which is used to improve workers' rights. With a sufficient impact on the retail price of a sweater - indicated by the participants to be between 1 and 7 percent of the price - such an initiative might, however, be said to be detrimental to consumer welfare and thus violate competition law. ${ }^{10}$ 
The agreement does, however, protect a noneconomic interest: labour standards in factories in poor parts of the world. Similar concerns have been raised with regard to a multiparty agreement between Dutch energy production companies (together with the Dutch Minister of Foreign Development) on providing transparency about the provenance of coal for energy production. This initiative was pushed by civil society organisations with the aim of raising awareness about the labour conditions in coal mines in underdeveloped countries. However, given only a limited number of energy production companies, transparency as to the provenance of coal individualised for each company leads to a danger of price collusion. Thus, this transparency obligation might lead to a restriction of competition on the production market, while protecting workers' rights in the coal mines at issue (whereas aggregated information might not give rise to collusion danger, this defeats the monitoring purpose of the civil society organisations). ${ }^{11}$

Second are public health standards. An example here is a joint effort in the UK to combat binge drinking, a seriously risky pastime for youngsters. ${ }^{12}$ Inner-city supermarkets, wanting to take responsibility for this danger to the health of young people by limiting the sale of cheap mixed drinks at going-out times, would want to join forces: if one of the supermarkets alone were to limit sales or raise prices significantly, it would lose market share. But together they might actually impact the occurrence of binge drinking. However, such a limitation on sales clearly constitutes an anticompetitive interfirm agreement, directly raising consumer prices (Townley 2008, 348).

Third, environmental or animal welfare protection may also raise frictions with competition law. A first example in this area relates to an agreement on enhancing animal welfare in intensive animal husbandry beyond existing standards. The interfirm cooperation included the supply chain of chicken meat, including supermarkets, and aimed to phase out poultry produced under conditions not very conducive to protecting animal welfare. The improved chicken, however, would be raised (and slaughtered) under slightly better conditions. Though enhancing the noneconomic interest of animal welfare, such an agreement increases production costs and might thus lead to an price increase of supermarket-bought chicken meat. ${ }^{13}$ As to environmental protection, an initiative limiting the emission of particulate matter and noxious gasses by agreeing on sustainable energy production through closing coal-fired power plants was held against competition law. This interfirm cooperation would lead to a higher price for energy; while at the same time, increasing health and long-term environmental stability. ${ }^{14}$ Other examples might be joining forces to protect biodiversity, protecting the precious layer of topsoil in plantations, or a move to less intensive farming methods. All lead to either an increase of production costs or directly to a charge on consumer price. ${ }^{15}$

In all these cases, legal authorities need to decide whether they will open up the space for a balancing act not just between positive and negative effects on consumer welfare, but between the consumer welfare interest and these noneconomic interests. ${ }^{16}$ The legal debate about these questions in the European context focuses on the interpretation of the relevant Treaty obligations. ${ }^{17}$ As indicated, the currently dominant interpretation would be that these noneconomic interests cannot easily be taken into account. ${ }^{18}$ The main reasons are that protection of health, social cohesion, 
and the environment are difficult to monetize: expressed in monetary terms in a similar vein as the consumer welfare impact. Also future benefits are not generally considered beyond the short term, and benefits not accruing to the consumers bearing the higher price are not generally taken into consideration (Gerbrandy 2017). Parallel to the legal debate, there is an economic debate about whether economic theorizing must be confined to consumer welfare or can be broadened so as to allow both consumer and nonconsumer welfare into the economic calculus, a so-called total welfare approach (Kerber 2007; Baarsma 2011; Kaplow 2012). In this article, our aim is to add to the debate by providing a different angle. The overall focus will be on the political aspects of the problem: Is it politically legitimate to allow firms to engage in collusive behaviour to further public interests? By engaging this question, we hope to give ammunition to those in legal and economic debates who defend the broadening of competition law, alleviating the worry raised by more orthodox legal and economic scholars that the political system cannot legitimately do so.

\section{FIRMS AND THE PUBLIC/PRIVATE DIVIDE}

The problem of interfirm agreements has been amply discussed in the legal and economic literature. We now contribute to the debate by exploring the philosophical dimensions of this problem, which have received limited attention. ${ }^{19}$ In doing so, we choose to conceptualize the problem as one of political legitimacy. In this section we will introduce this focus and place the problem of interfirm agreement in the context of the larger debate about the status of firms/corporations ${ }^{20}$ in liberal-democratic theory. As we will make clear, the demand for legitimation of interfirm agreements that we identify in this section is an instance of a more general demand for the legitimation of corporate actions.

It is useful to think of the cooperation/competition problem as being structured as a choice between three different ways of honouring public interests, both from the point of view of private firms and for political actors writing competition laws. Each strategy has distinctive advantages and drawbacks.

A first possible solution, in the face of a pressing public interest, is for firms to ' $\mathrm{go}$ it alone' (i.e., take unilateral action). This is the quintessentially private solution, to use one's market freedom to address the problem. The business ethics literature is replete with examples of firms making a special strategy out of beyond-compliance behaviour (i.e., there is a niche market for leaders in corporate social responsibility [CSR]). In this case, pursuing public interests might also be profit maximising. Such a strategy does not usually raise competition law problems, because there is no collusion which would bring it under the scope of the provision against anticompetitive agreements. ${ }^{21}$ As this route shows, we should not believe that consumer interests and the broader, noneconomic interests described in the previous section are always and necessarily in tension. A situation in which consumers are expressing a demand for (higher priced) products with enhanced noneconomic features is one example where there is no such tension. However, there are often practical limits to this strategy. It may amount to corporate suicide, especially in heavily competitive contexts. ${ }^{22}$ Then firms would have to opt for one of two other strategies. 
A second option is the solution we will refer to as interfirm cooperation. From the point of view of the firm it has the advantage of creating a level playing field so that a firm does not face the suicidal risks associated with unilateral action. Of course, compared to government regulation (see below), interfirm cooperation is more demanding for firms in terms of the deployment of time, knowledge, and resources. From a political perspective, interfirm cooperation decreases the burdens on government and may lead to better rules where firms have better inside knowledge of the issues at stake. These interfirm solutions can have different forms. Standard setting (in the form of a 'green' label), for example, will not generally have a competition effect as long as the scheme is both transparent and open to participants, and when there are alternative schemes available for market parties. ${ }^{23}$ However, where labelling and standard setting lead to price effects these become problematic from a competition law point of view. Furthermore, as the examples above show, initiatives may go beyond green labelling or, necessarily or not, take the form of a direct interfirm agreement. If such an agreement does not concern competition parameters, it will not generally be prohibited by competition law. However, as soon as there is an (even potential, even indirect) price effect, this type of interfirm cooperation might lead to competition law conflicts. ${ }^{24}$

Third, there is the quintessentially public road, to go for government regulation. The advantage of regulation, for the firm, is similar to the advantage of interfirm cooperation: it creates a level playing field, so that firms are not required to sacrifice their own interests as long as other firms do not do so as well. And there is no competition law risk. ${ }^{25}$ The problem is that regulation may be unattainable in many situations. There may be political gridlock, lack of expertise or information on the part of regulators, obstruction of regulatory efforts by other market participants, a fast market dynamic which resists meaningful codification, etc. These causes have been behind the rise of corporate social responsibility (whether unilateral or not) in the last decades.

This tripartite scheme shows that interfirm cooperation is an intermediate option between purely private and purely public action. ${ }^{26}$ Some may be inclined to think of this strategy as residual, an option of last resort to be considered only when both purely private and purely public strategies are impossible. We prefer to keep our consideration of the issue more open, however. Interfirm cooperation may actually be preferable, all things considered (on whatever normative criterion), even when one or both other options are possible. The analytical scheme leaves open the normative question about the legitimacy of these courses of action.

With this scheme as a structuring device, let us now turn to such a normative assessment of the rightness or wrongness of interfirm agreements. This assessment can be undertaken using many different values. One could focus-as economists and utilitarians do - on evaluating the welfare effects of these agreements or, as is most standard in political philosophy, on whether these agreements are socially just (fair). These two types of analysis—looking at efficiency and justice-are important, and we have written about the problem from this angle elsewhere. ${ }^{27}$ They together provide a first-order normative assessment. Given the fact that there will be inevitable reasonable disagreements between citizens about the correct standards 
of justice however, mainstream liberal political theories recognize that there is an important second-order normative question to be answered: how to resolve disputes about first-order normative questions legitimately. The notion of legitimacy is taken by most theorists to comprise a less demanding standard, in the sense that citizens who disagree on the justness of a political decision should still be able to recognize it as legitimate - as a decision that they have a moral reason to obey when it emanates from a political authority which is legitimately exercised.

Notice that by focusing on legitimacy, we presume in the following that (under some conception of justice) there is a subset of interfirm agreements that are mandated by justice: these agreements provide the fairest way to balance the economic and noneconomic interests at hand. An interfirm agreement in this subset of cases is the only (or the most effective) way of doing justice to the interests at stake, given an estimation of the feasibility and costs/benefits of the three options (unilateral action, interfirm cooperation, and government regulation). Whether there is such a subset, and how we should go about making these estimations, are questions to be discussed elsewhere. In this article, our focus is different. We inquire whether interfirm agreements (given that it is controversial which of them belong in the subset) are subject to a legitimation demand, and if so, how they can meet this demand. In standard treatments, nation-states (and lower-level governments) are taken to be the primary subjects of legitimacy demands. It is increasingly recognized that this might draw the circle too narrowly, but when this is recognized, attention usually focuses on the question whether - in an era of globalization-we should now also recognize legitimacy demands for international or global public institutions (Buchanan and Keohane 2006; Peter 2010). Parallel to this issue, however, there is the issue of increasing the scope of legitimacy demands beyond the state in another direction: the private sphere. Should firms-both in general and when concluding interfirm agreements_-also be held accountable for their actions?

For a long time, this has been thought impossible since firms are quintessential private institutions and 'political legitimacy' can only be a standard applicable to public institutions. According to a standard picture, liberal-democratic societies are premised upon a clear dividing line between the private and the public domain. Private actors can pursue their own interests (individually or in association with others) while public actors regulate the private domain so as to safeguard public interests (Benn and Gaus 1983; Weintraub 1997). First amongst these public interests is an orderly set up of the private sphere itself, so that individuals do not harm each other's basic liberty and security. The social contract tradition legitimizes this division of labor by justifying the task of the state in terms of a harmonization of the potentially conflicting interests of private citizens. The liberal-democratic order breaks with a feudal past in which public offices were merely a cover up for the private interests of ruling aristocratic classes and the monarchy. This simple scheme has often been attacked as descriptively inadequate, since even in liberal-democratic societies the public and private domains have interpenetrated each other in myriad ways from the beginning (Stark 2010). But even if the actual reality is messy, the simple private/public divide template has continued to fulfill a normative functionbelief in it continues to serve as an apparently useful fiction (i.e., to separate out 
those institutions which are to be held accountable for serving public interests). Private and public should be kept apart because not doing so harbors the danger of corrupting both spheres. This argument has, for example, been very prominent in debates about the privatization of public services. ${ }^{28}$

Following this standard picture, the normative issues surrounding firms have been discussed in the area of business ethics. The framing of firm obligations as having ('merely') moral obligations reinforces the dichotomy between the public and the private, with firms falling on the private side of the distinction. Controversial firm actions may violate moral obligations, but this will only attract moral blame or praise, not a demand for democratic accountability, as would be the case with controversial actions by a public institution. In recent years, however, the essentially private view of the firm has been challenged in an emerging literature on 'political CSR,' ${ }^{29}$ and on the political theory of corporations (McMahon 2012; Singer 2017), which does treat firms as - at least partly_political actors. A landmark contribution is made by Ciepley (2013), who argues that a close analysis of the history and legal status of corporations reveals that they fall in between the private and the public sphere. They occupy a hybrid or third sphere which cannot be assimilated to either side. For Ciepley there are two main reasons for this classification. We will here briefly summarize them, since we want to build upon this framework in the following sections.

The first reason is that law grants corporations contractual personality as well as special privileges with respect to the exercise of property rights which are not granted to normal individuals (limited liability is the most familiar one; the other two Ciepley discusses are 'entity shielding' and 'asset-lock-in'). These legal privileges give firms the ability to pool and invest massive resources from multiple shareholders into a new, collective agent, which can act on its own behalf and gain enormous de facto power in economic life. The problem, Ciepley argues, is that they, while allowing great productivity gains, also open up the possibility of irresponsible behavior. Property is 'socialised' into a new entity, and as is familiar from debates about socialism, this creates a risk that nobody will take adequate responsibility for harmful exercises of these property rights. This problem may be manageable, but what is most remarkable about Ciepley's argument is that he shows that market liberals' reaction to this problem is counterproductive. Their reaction is to try to close the gap between shareholders (principals) and corporate management (agents) by holding the latter accountable to the former. However, given limited liability, the corporation is then run in the interests of shareholders, who experience "a floor on their losses, but no ceiling on their gains" (Ciepley 2013, 148). This shareholder ideology creates a short-term dynamic which causes more bankruptcies and diminishing investments in productive activities, thus undermining the corporation's primary commercial mission itself. More adequate legal arrangements need to recognize these risks and be based on a more adequate political-philosophical foundation than the market liberal's counterproductive reaffirmation of the corporation's private status.

The second reason for resisting an assimilation of corporations to the private sphere has to do with the internal authority of corporations over their workers. Ciepley attacks the two prevailing views, which justify this authority as emanating from the labor contract between the corporation and workers or from the ownership 
of corporate assets. He shows how both justifications cannot adequately explain the authority relationship; the former because it is incomplete and refers to the latter, and the latter because it relies on the mistaken view that shareholders own the corporation. The authority of corporations, Ciepley argues, derives from the corporate charter, hence, from government. Governments have throughout history created corporations (both profit and nonprofit ones such as universities, towns, and hospitals) through the corporate charter, which legally creates the corporation and specifies its mission. This, according to Ciepley, creates a legitimate internal jurisdiction for the corporation in which management can have authority over workers (Ciepley 2013, 149-51). As he states: "The history of corporations is a history of 'sovereign' institutions (such as church or state) authorizing inferior institutions (corporations) to do things that the sovereign institution wants done but is unable or unwilling to do itself.... Corporations are institutions of delegated government" (Ciepley 2013, 151, emphasis ours). This squarely positions the corporation as an instrument of the core public institution (state), even though its day-to-day operations after its creation are allowed to work on the basis of private contract and private property.

For a fuller discussion of both of these points, we refer to Ciepley's paper. But if (admittedly a big if ${ }^{30}$ ) something like his view of the corporation is right, and the corporation is a partly public institution, does this mean that interfirm agreements are subject to demands of political legitimacy?

\section{THE SCOPE OF POLITICAL LEGITIMACY: FIRMS AND THE BASIC STRUCTURE}

The first step to answer this question is to consider what the scope of legitimacy demands should be (i.e., which decisions should be subject to such demands). Only if we have established that firms fall within this scope can we, in the next section, approach the issue of the content of such demands (i.e., the form that firm accountability should take).

The scope of legitimacy refers to the delineation of the category of decisions in need of public legitimation. The main philosophical literature in which the question of the proper scope of legitimation has been considered is the discussion of the concept of the 'basic structure' in John Rawls's theory of justice. Rawls argued that only the institutions which belong to the basic structure of society are susceptible to demands of justice. This triggered a discussion about which institutions belong to the basic structure. This discussion may seem to be beside the point, since we focus on legitimacy, not justice. However, we feel justified to apply the same criteria, not only to demands of justice, but also to demands of political legitimacy, given that institutions which are subject to 'first-order' demands of justice are also subject to the 'second-order' demands of legitimacy, given reasonable disagreement about justice (see the connection we drew between both in the prior section). In this section we will use the terminology of justice-since the discussion about the basic structure is in these terms - but the results of the discussion should be understood as extending to demands of legitimacy as well.

Rawls defines the basic structure as including the "political constitution and the principal economic and social arrangements" or again, as the institutions which 
"define men's rights and duties and influence their life prospects, what they can expect to be and how well they can hope to do" (Rawls 1999, 6-7). His theory is somewhat ambiguous about the criterion to determine what exactly falls under the basic structure. Arash Abizadeh argued that there are at least three possible interpretations: those institutions which regulate the terms of social cooperation, those institutions which have a pervasive impact upon people's life chances, and those institutions which subject people to coercive measures (Abizadeh 2007). We will not engage in an exegetical debate about Rawls, but assume that the third interpretation is substantively most attractive. This interpretation, which is widespread in liberal theory, states that institutions which exercise coercive power, from which citizens cannot escape, are in need of political legitimation (e.g., Ripstein 2004). Our question is whether-on the analogy with state action-firm action can be interpreted as coercive for citizens.

This question has been answered negatively by Abraham Singer, at least as a matter of Rawls's interpretation. He argues that Rawls's theory of justice defends the distinction between the public and the private sphere. Exit from the coercive influence of the state's decisions is not an option (except for emigration, which depends on burdensome and sometimes impossible options for immigrating to another state). By contrast, private associations are voluntary and citizens can practice their right of exit. This may be thought to make the criterion of coercion into a merely legal one. In a liberal society which protects basic rights, everyone is legally free to exit private institutions. This is true for firms as well: workers can resign from their jobs and consumers can stop buying products of firms they dislike. Singer points out that under Rawls's theory, provided that the basic structure is just, everyone has sufficient resources to make these economic decisions to exit firms. Rawls's principles of justice demand a wide dispersal of ownership amongst everyone, and under this condition, everyone enjoys effective possibilities of exit. If the basic institutions (e.g., state taxation and redistribution) do their work, we don't need to impose any additional demands of justice on corporations. The division of labour between the public and the private is upheld (Singer 2015, 79-82).

In a reply, Sandrine Blanc has criticized Singer's arguments. Her main point is that Singer thinks about the question as one about single firms. However, the question should be taken as one about corporate governance as a whole. She argues that no citizen (unless by leaving the territory) can exit from the profound effects that corporate governance structures - as created and enforced by law-have on citizens. One can exit a single firm but one cannot withdraw from economic life altogether, with its direct and indirect effects on our living conditions (Blanc 2016, 414-17). We agree with the substance of this argument (how this impacts upon Rawls, we leave out of consideration). Corporate governance law is coercive where it applies (i.e., to those economic agents making use of the corporate form). Moreover, this form applies so broadly that escape from it is, in the current economic landscape in most countries, fictional. This triggers demands of justice for corporate governance law; this part of the law belongs to the basic structure. However, this conclusion about corporate law doesn't mean that whatever actions corporations undertake (either alone or together) within the boundaries established by law are also subject 
to demands of justice, for otherwise every corporate action to further some public interest would always be subject to demands of democratic legitimation. This would stretch the boundaries of political legitimacy too far, given that many actions by corporations are escapable, and hence noncoercive, for citizens. ${ }^{31}$

Switching back now from corporate governance law to the competition law context, we can raise the analogous question about the coerciveness of corporate actions. ${ }^{32}$ The crucial point we want to defend in this context is that in contrast to unilaterally acting firms (as long as they have no dominant position), interfirm agreements leave consumers no choice. In the type of public interest initiatives touched upon above, this 'leaving no choice' is often a necessary requirement of this type of agreement in order to function. The initiative covers the complete market (or market segment), so as to prevent undercutting by a maverick company-in which case the public interest aim is not achieved - and to prevent free riding in which case non-investing firms hitch a ride on the back of the other firms' investment. The examples of agreements discussed above cover most of the (or even the complete) relevant market, precisely because this is deemed necessary for obtaining the public interest. But of course, if the agreement covers all producers, consumers have no other supplier to turn to to buy the goods at a lower price. Consumers will have no choice but to bear the burdens - pay the higher price - of firms acting in the public interest. These agreements therefore create a legitimation problem, which is the same as the one faced in the case of public authorities: the employment of coercive means from which there is no escape.

One may want to object that consumers can turn to substitute products. If, for example, chicken farmers and large supermarket chains agree on providing a more sustainable chicken to be sold through the supermarkets to the exclusion of the hitherto less sustainable chicken, there is still the possibility of purchasing a non-sustainable chicken through other venues. ${ }^{33}$ In addition, consumers may choose to buy another type of meat instead of chicken or stop eating meat altogether. The objection shows that the nature of the coercion is, in part, an empirical matter (just as for the state: one can also object that emigration is always possible, even if very difficult). Indeed, these empirical matters are part of the assessment of any agreement under competition law where the consumers' reality is taken into account. The question then becomes whether buying non-sustainable chicken at a different outlet is a viable option for an average consumer purchasing weekly groceries at the supermarket. The assessment also covers the reality of the option of switching to another product altogether. Thus, substitutability is taken into account when delineating the 'relevant market,' that segment of market relations where the effects of the agreement are felt. ${ }^{34}$ It is only when there is genuine market power, on the defined relevant market, that the agreement is caught by competition law. ${ }^{35}$

Considering the above, we propose to set the bar for coercion not too high, in conformity with the existing competition law framework. The criterion of coercion is not merely formal, but demands effective options for exit. Where such effective options are absent, there is coercion. We will accordingly assume that consumers are coerced in legal cases such as the ones discussed above (in the second section). 
This approach extends and specifies both of Ciepley's points about the public nature of the corporation. His first point was about the need for arrangements which guarantee corporate responsibility in response to the social risks generated by their property-based legal privileges (hence de facto power), so as to attain their primary mission: a productive allocation of resources. We agree with Ciepley's point that the power and privileges of corporations make them difficult to assimilate to the private category of natural persons. Given these powers and privileges, the social risks involved in corporate action seem to provide a reason to demand public legitimation; don't public interests come into play? In this context, the argument in this section is useful since it specifies that this concern about corporate actions only raises a legitimation demand for corporate law on the one hand and interfirm agreements on the other, not for all corporate action as such (but see note 31 ), since only the former have coercive effects for all citizens. Moreover, Ciepley tends to conceptualize the public interest at stake in corporate action in economic terms, as the productive use of resources. The phenomenon of interfirm agreements shows how this needs to be broadened to include noneconomic interests as well. Since firms can impact noneconomic interests, this is an additional reason to scrutinize their behavior, wherever it is inescapable.

Ciepley's second point was about the justification of corporate authority. Ciepley confines his discussion to the authority of corporate management over workers. The case of interfirm agreements however shows that firms also exercise authority over parties external to the corporation. The nature of firms' authority is different with respect to external parties, since it cannot be based on an employment contract. Instead, it relates to authority exercised in the context of either some other type of contract (as with consumers) or a noncontractual relation (as with a firm's effects on third parties, say, on animal welfare). Ciepley's justification of corporate authority does not rely on a contractual basis. His main point was that corporate authority should be seen as derived from government in a delegated structure. This is a justification of authority which - in contrast to justifications relying on the employment contract-allows exercises of authority over external parties to be brought into the picture. Hence, it is congenial to discussions of interfirm agreements. Whether interfirm agreements can be legitimated on this basis, however, remains to be seen; we will discuss this in the next section. ${ }^{36}$

In conclusion, interfirm agreements - where they are the only just or most effective way of solving a conflict between economic and noneconomic interests-do raise a demand for political legitimation. The question then becomes: What is this demand, and can it be met?

\section{HOLDING FIRMS TO ACCOUNT: DELEGATED GOVERNANCE}

In this section we will argue that interfirm agreements can be legitimated. Starting from a standard view of democratic consent, we propose a model of delegated decision making to do so, and connect this to Ciepley's argument about corporate authority as well as the empirical literature on self-regulation by firms.

The standard criterion of political legitimacy in liberal-democratic theory usually is some form of consent: decisions are legitimate if they are taken by an institution which is authorized through consent of those subject to its decisions. Here, a distinction 
must be drawn between the legitimacy of government authority per se (e.g., through some form of original consent in the creation of a social contract) and daily decisions by specific governments at a second stage. The latter are legitimate to the extent that they are democratically consented to by the population. Our discussion is situated at this second stage. Debates in democratic theory are about how to flesh out this demand for democratic consent: which mechanisms of democratic decision making to use (e.g., majority versus unanimity voting, agenda setting procedures), how to implement a link between decisions and popular consent (direct versus representative democracy, different electoral systems, etc.), how to delineate the people whose consent counts (minors, prisoners, immigrants), etc. These debates need not concern us here. The key question for our purposes is: Can interfirm agreements be understood as democratically legitimated, and if so how?

At first sight, on the criterion stated above, firms seem to fail the test, for they are not democratically legitimated through elections, such as governments are. To escape this conclusion, we propose that the criterion of legitimacy needs to be reformulated. Decisions are legitimate not only if they are actually taken by a democratically legitimated institution itself, but also when they can be (but are not) overruled by such an institution. Underlying this reformulation is the thought that public decision making in modern societies is often delegated decision making. Usually, delegations are based on express administrative law provisions and give decision making power to (quasi-)independent public agencies. Regulatory agencies overseeing market activities are one example, which remain within the ambit of the public system of decision making as a whole. The same cannot be said about private firms: their daily actions in the market, governed by the laws of private contracts and private property, cannot be said to be part of the usual system of legitimate public decision making. When they engage in interfirm cooperation, the only way for this to become legitimate is to provide oversight by other agents, which do have democratic legitimation. Hence, we propose a model of legitimacy which has sequential decision making at its core. More specifically, interfirm cooperation should be seen as the first stage of a three-stage sequence. ${ }^{37}$

In the first stage, firms, either pressured by consumers, NGO's, or even government, or out of their own intrinsic motivation 'to do good,' decide to cooperate with other firms to set industry-wide standards for environmental protection, labour protection, or some other public interest. This decision involves a controversial trade off between this public interest and consumer interests (higher prices). Firms acting together can claim that they are morally under a duty to decide the balancing act in favor of the public interest, but this claim is rebuttable. Given its coercive nature, the decision comes under review by regulatory agencies charged with the enforcement of competition law. This is the second stage. These agencies, however, often feel insufficiently democratically motivated to take these public interests into account. The weaker democratic legitimation of these agencies (no direct elections) corresponds to a narrower mandate, which is to focus on economic expertise and leave noneconomic interests out of consideration. They prefer to balance economic against economic interests (e.g., short-term higher prices against long-term innovative potential). Once they are required to balance economic versus noneconomic 
interests, the nature of decision making is felt to shift from a technocratic to a political exercise. This is why opponents claim that regulatory agencies lack the legitimacy to assess noneconomic interests (Loozen 2015; Mulder 2016, 176-177, 207). They advocate separate regulations for protecting public interests so that the competition law system can remain purely concerned with economic interests.

These arguments do not provide a good reason to deny regulatory agencies the power to assess these cases. However, they do require us to acknowledge a third stage. If a regulatory agency makes a decision about noneconomic interests and others feel that this decision is so controversial so as to require more democratic legitimation, at that point fully democratically legitimated agents (parliaments and governments) can respond by taking up the issue, overruling both firms and regulatory agencies, and adopting a law in which they define and protect the public interest at stake (for a similar view, see McMahon 2012, 107, 157). Thus, at the end of the chain, the potential intervention by governments and parliaments plays an important justificatory role, even if at the beginning the justification for allowing interfirm cooperation lies in the fact that legal regulation may be less feasible or efficient (for the reasons mentioned earlier). Their silence on the issue is a form of 'tacit consent' which legitimizes the actions of private actors and/or regulatory agencies. This proposal to think about political legitimacy in terms of sequential decision making in our view provides an important improvement. It shows what usually remains hidden in democratic theory: the legitimating power of potential decisions by higher-up actors in a chain which begins with purely private actors and ends with the most strongly democratically legitimated actors. In an economy in which private and public actors are increasingly both involved in actions touching upon public interests, such a revision is an improvement over standard models keeping the public and the private neatly separated.

Our proposal of delegated decision making fits nicely with Ciepley's (2013) view of the corporation as a form of delegated government. As with the discussion in the previous section, we need to extend Ciepley's position about corporate authority over workers to the external dimension (i.e., the authority firms exercise over consumers and other citizens). We reach a similar conclusion with respect to the external dimension, at least where interfirm agreements are at stake. There are two major differences, however. First, while in Ciepley's argument delegation is effected through the corporate charter, in our three-stage sequence is it effected through a tacit approval by governments of interfirm agreements in the public interest (alternatively, one would have to construe the charter as implicitly containing this approval). Second, the demand for democratic governance, however, does not point to direct involvement of all those affected (all stakeholders who feel the impact of a certain interfirm agreement), but follows the chain of delegated accountability upwards, through regulatory agencies and finally, parliament. Stakeholders can have their voices heard in each of the stages of the sequential decision-making process, within the procedures established by each of these public institutions.

Finally, our proposal also matches with the results of empirical studies as to the success of private industry self-regulation by individual firms and co-regulation by industry associations, both as alternatives to traditional command-and-control 
regulation by the state. Summarizing decades of research on this topic, Balleisen argues that if well crafted, self-regulation and co-regulation can enhance the protection of public interests compared to state regulation. To realize this potential, however, he formulates a set of eight conditions which public regulators must take into account. Public agencies must set and enforce reporting requirements, publicize the regulatory performance of firms, facilitate the professionalization of private regulatory officers, undertake periodic inspections, empower supplemental nongovernmental watchdogs, and last but not least, retain the capacity to impose further reaching regulatory standards where self-regulation fails (Balleisen 2009; see also Balleisen and Eisner 2009). These conditions are meant to ensure that private industries take self-regulation seriously and require a serious strategy and investment of resources from public agencies themselves, which is characterized as governmental 'meta-regulation' (Coglianese and Mendelson 2010). What the eight conditions for successful self-regulation express, is the crucial role of accountability and transparency of private firms towards public regulators. Both remain connected, and the latter remain heavily involved, if in a different role. It is precisely this demand for accountability which we have tried to capture in the model of delegated decision making and which can grant legitimacy upon interfirm agreements to further public interests.

\section{TWO PRACTICAL OBJECTIONS}

To substantiate the line of argument developed in this article, we do, finally, need to deal with two objections often put forward against taking public interests into account in competition law cases. One objection is that incorporation of public interests in competition law will lead to hypocrisy on the part of firms. They will try to make excess profits on the backs of consumers under the guise of such agreements (call this the hypocrisy objection). The second objection argues that taking public interest into account in competition law cases will lead to an unworkable and unpredictable system of law: it will result in a hopelessly complicated workload for legal practitioners at regulatory agencies and courts (call this the infeasibility objection). The objections work in tandem and are both summed up nicely in the following quotation:

The distinction between a trust aimed at limiting competition and an industry association aimed at environmental protection is a matter of perspective. What is judged positively by one party may be seen as undesirable by another. That is to say: inter-firm cooperation cannot be allowed for on a well-organized market because there are no reasonable, let alone objective, criteria by means of which we can distinguish reasonable exceptions from unreasonable ones. Since it is all 'a matter of perspective' the risk is simply too big that we are only serving some partisan business interest, cleverly disguised as a CSR initiative. Thus, we are confronted with an either/or decision: either we lock out any form of inter-firm cooperation (and accept the possible disadvantages of that decision because the advantages are much bigger) or we will end up in the swamp of exceptions and subjective arguments that will in the end disrupt the working of the competitive free market system (Dubbink and Van der Putten 2008, 383). 
Both arguments point to an epistemic problem for public authorities: will they be able to discern genuine from fake cooperation and be able to weigh all interests involved? Both issues also tie in with the legitimacy issues discussed above, for if the answer is that authorities cannot, then the resulting system cannot be accepted as legitimate. These are, therefore, serious allegations. But they must be rejected.

Let's turn to the hypocrisy objection first. We imagine a scenario in which a group of firms would stress that the purpose of an interfirm agreement is a public interest (e.g., protection of biodiversity or enhancing animal welfare) while actually they only want to profit by raising consumer prices. Would such a plot mislead competition authorities, agencies, and courts? We should remember that in standard competition law assessments, it is first and foremost the economic effects (on consumer welfare) which are investigated (in the EU under the prohibition of article 101 par. 1 TFEU) and only secondly the possible benefits that come into the analysis (in the EU usually under the exception of article 101 par. 3 TFEU). This does not in essence change when noneconomic interests are taken into account. Here, too, the benefits obviously need to be substantiated. ${ }^{38} \mathrm{~A}$ 'fake' interfirm agreement would therefore raise red flags under the first limb of this test and would not hold up to scrutiny under the second limb.

Some examples may drive this point home. In a case in which producers of washing powder tried to defend a price cartel by claiming that its aim was the improvement of environmental performance of their products, the Commission concluded "the environmental objective did not require them to coordinate their prices." ${ }^{39}$ In another case - already mentioned above — the competition authority found that the public interest goal of providing transparency in the coal production sector could not be reached by the restrictive information obligations imposed on the parties to the agreement. Finally, when Italian geologists argued that their code of conduct, in essence leading to an agreement on minimum tariffs, was necessary for the standing of their profession, this was contested before the Court. ${ }^{40}$ The hypocrisy objection thus falls short, because hypocrisy will be-and already is - recognized by competition authorities when taking noneconomic interests into account, just as much as it is-or should be-recognized today when they consider the clash of economic interests. This does not take away the fact that there is always a danger of straying into areas of grey_or even black — during interfirm meetings when discussing the terms or the implementation of legitimate public interest cooperation. But competition lawyers, including in-house counsel, are acutely attuned to this danger and would guide discussions between firms to stay clear of the grey and black zones. If anything, because of this acute awareness - and the possibility of harsh sanctions, especially in competition law systems where enforcement action might lead to personal fines and imprisonment-firms might actually shrink back from legitimate discussions of noncompetition issues and thus hold back the development of interfirm cooperation (OECD Global Forum on Responsible Business Conduct, 19 June 2015). ${ }^{41}$

Let's turn to the infeasibility objection. In situations of genuine public interest cooperation, it might be difficult to construe or calculate the benefits resulting from the cooperation, so as to balance these against a detrimental effect for consumers. 
Part of this argument is covered by the allegation that the legal system becomes messy, and that the epistemic burden on competition authorities to balance all interests involved becomes too great (Odudu 2010; Baarsma 2011). Another element relates to the legal uncertainty which might exist as to the standard to be applied, the methods to be used, and the question as to which interests, if any, are to be taken into account in a balancing between economic and noneconomic interests. It is undeniable that the necessary balancing of different interests can be difficult. But not only are there examples of competition law regimes where such a balancing is called for in the legal system itself, ${ }^{42}$ but balancing multiple interests is in itself a normal legal method of decision making involving multiple interests (Townley 2008, 356). Balancing interests is inherent in the widely used legal proportionality test and is thus commonplace in legal reasoning, for example, in human rights litigation (Klatt and Meister 2012). Even balancing of seemingly incomparable interests, such as balancing the protection of the economic value of creating a European internal market with the noneconomic value of protecting human rights, is not out of the ordinary scope of legal reasoning (De Vries 2013). We do not deny the complexities involved and, indeed, these complexities are an added reason for rethinking the decision-making procedures in these cases, especially at the competition agency level. But the idea that balancing in competition law cases would lead us to a 'swamp' (as envisioned in the quote above) is fairly dubious. ${ }^{43}$

A legal elaboration of each of the three stages of our legitimation model would be necessary. In the first stage, firms would have to undertake a self-assessment of the resulting positive and negative effects, both of economic and noneconomic interests involved. ${ }^{44}$ In the second stage of agency or court supervision of interfirm cooperation, procedural refinements can, and probably should, be added. For example, a choice for formal or informal notification and authorisation could be made. Interfirm cooperation which has included government representation in its gestation phase, or includes continuous NGO involvement and monitoring, might receive less intense scrutiny than where this involvement is absent. Regulatory agencies might also enhance the legitimacy of their decision-making procedures by including a form of direct democratic participation (Gerbrandy 2015).This is especially salient where a balancing act leads to a stalemate between the different interests involved and the discretionary power of the regulatory agency or court is greatest. The challenge for both firms and agencies would be to provide both clarity of reasoning and transparency in the balancing act involved, so as to allow for a maximally informed third stage of legislative oversight, in those (we expect) rare instances where it will take place.

To conclude, both objections are far from fatal to the case defended in this article for adapting our idea of political legitimacy to make room for firms to cooperate to realize public interests. The article has attempted to show in this one area how under the cover of seemingly technical legal developments, developments of great moral and political importance are happening. Shifts in governmental capacity, as well as societal expectations about solving environmental, labour, and public health issues, may require us to reconceive established views of the market, of the virtues of competition, and of the boundaries of private and public responsibility. 


\section{ACKNOWLEDGEMENTS}

The authors would like to thank audiences at the annual conference of the Dutch Research School of Philosophy (Amsterdam, 2015) and the workshop on Justice and Democracy in the Firm (University of Barcelona, 2015), especially Axel Gosseries, for their comments. They also thank BEQ associate editor Jeffrey Moriarty, as well as three meticulous reviewers for the journal, for their very helpful comments and suggestions.

\section{NOTES}

1. Quoted in Northern Pac. Ry. V. United States, 856 U.S. 1, 4 (1957).

2. The Court of Justice of the European Union—its highest court—has not supported the position that consumer welfare is the only goal of European competition law. It has held that there are other goals as well. See Witt (2012) and Monti (2013) and especially the following cases: Case C-52/09 Konkurrensverket v. TeliaSonera Sverige AB, para. 22 (not yet reported); see also Case C-94/00 Roquette Frères (2002) ECR I-9011, para. 42; Joined Cases C-501, 513, 515 and 519/06 P GlaxoSmithKline et al. v. Commission (2009) ECR I-9291, paras 63, 64; Case C-8/08 T-Mobile Netherlands BV et al. v. Raad van bestuur van de Nederlandse Mededingingsautoriteit (2009) ECR I-4529, para. 38; T-86/95, Compagnie Maritime Belge and others v. Commission (2002) ECR II-1011, para. 343; Joined Cases T-528/93, T-542/93, T-543/93 and T-546/93 Métropole Télévision I (1996) ECR II-649.

3. The position of the BRICS countries is especially interesting here as they have incorporated USA/ EU-inspired competition rules in their legal systems, but seem to have never completely conformed to the consumer-welfare economics-based goals expressly embraced in the EU and the USA. See (Jenny 2016; Poli 2015).

4. Merger control falls outside the scope of this article, though — as with the prohibition on abuse of dominance-similar tensions might arise. Some merger control regimes allow a public interest defense against an anticompetitive merger. Relying on such a defense is usually only possible in very limited circumstances; the decision on accepting the defense is generally lifted from the competition authorities and placed in the hands of a Secretary of State (or similar politically accountable office). This, combined with the different procedures which often involve an ex ante scrutiny of proposed mergers, makes the legitimacy-issue of corporations deciding to forge a merger in the public interest less of an issue. See on the different regimes OECD paper of the Directorate for Financial and Enterprise Affairs, 30 June 2016 (DAF/COMP/WP3[2016]3).

5. Different systems of competition law (antitrust law) include equivalent prohibitions.

6. A variety of economic theories can be used to explain these prohibitions. For overviews see Budzinski (2008) and Pera (2008).

7. Therefore not all agreements are prohibited: only those that restrict competition in this sense. Many agreements between companies, in practice, do not relate to parameters relevant to competition and thus fall outside the scope of the competition law provisions.

8. In the USA, this is the core of the 'rule of reason': a jurisprudential rule that ensures only 'unreasonable' restraints on trade are prohibited (Standard Oil Co. v United States, 221 U.S. 1 [1911]).

9. The terminology of 'economic' versus 'non-economic' interests in this debate is unfortunate, since many of these non-economic interests could be represented in a broader welfarist calculus (for an example, see Kingston 2010, 798ff). It would be more accurate to speak of consumer welfare versus third-party welfare interests, but to avoid confusion, we will stick to the prevailing terminology.

10. See http://www.fairwear.org/ul/cms/fck-uploaded/documents/policydocs/OpiniontoFWFTheApplicationofEUCompetitionLawtoFWFLivingWageStandardfinal1.pdf. This legal opinion for the Fair Wear Foundation concluded that the impact on price would be too marginal ('not appreciable') to constitute a competition law infringement. To our knowledge, no formal decision by a competition authority has been taken on this issue.

11. See this particular example: http://www.government.nl/news/2014/11/17/government-andenergy-producers-sign-voluntary-agreement-on-coal.html. On transparency in the coal-mining sector see: https://www.acm.nl/nl/publicaties/publicatie/13544/Advies-ACM-over-herkomsttransparantie-inde-steenkolenketen. 
12. The case is described in more detail by Townley (2008), but was also covered by press. See for example: http://www.independent.co.uk/news/uk/politics/tesco-backs-pricing-call-over-binge-drinking-785101. html; https://www.theguardian.com/society/2008/mar/01/drugsandalcohol.supermarkets.

13. On enhancing animal welfare: https://www.acm.nl/en/publications/publication/13789/ACMsanalysis-of-the-sustainability-arrangements-concerning-the-Chicken-of-Tomorrow.

14. On limiting noxious emissions: https://www.acm.nl/nl/publicaties/publicatie/12033/Notitie-ACMover-Sluiting-5-Kolencentrales-in-SER-Energieakkoord.

15. As far as we are aware, there is no decision yet on these specific issues; but for an initiative to improve the management of palm-tree small-holders to prevent further deforestation (and its possible conflict with competition law), see: https://news.mongabay.com/2016/07/under-government-pressurepalm-oil-giants-disband-green-pledge/.

16. In the EU the legal analysis generally starts with the question of whether the agreement is an 'object'-infringement. This is close to (but not the same as) the notion of persé-infringements in the US system of antitrust law. A specific agreement might be differently labeled between these jurisdictions. Applying a consumer welfare standard does not preclude competition law from prohibiting as anticompetitive an agreement leading to higher production costs, even if producers choose to internalize (part of) these increased costs, rather than having them reflected in a higher consumer price.

17. In this context, the question is whether the exception clause can be broadly interpreted so as to include noneconomic interests. See for examples of the European legal literature around the topic Monti (2002); Cseres (2007); Townley (2008); Kingston (2010); Zimmer (2012); for the US context see Scott (2016).

18. In the European context, but also in the US, see Schmitz (2002, 548); Davies (2010, 65); Stucke $(2012,566)$. This is also true in Australia, for example, which does provide a legal exception for public interest-based cooperation, but which is nonetheless interpreted much in conformity with the approach in the US and the EU (Australian Competition and Consumer Commission. 2013. Authorisation Guidelines. Available at https://www.accc.gov.au/publications/authorisation-guidelines-2013. See also Bos (2002).

19. There are a few exceptions in the area of business ethics; see Dubbink and Van der Putten (2008); Wempe (2009); Herzog (2017).

20. We will use both terms as synonyms, given that the former is more common in economics, but the political discussion focuses on corporations. The latter legally have some specific features compared to non-incorporated firms, but the differences are not essential to the argument here.

21. Though we leave the competition law provision on the prohibition of abuse of a dominant positionpresent in most competition law systems and in the TFEU laid down in article 102 - aside here, it must be pointed out that even the going alone route might raise competition law issues where the result would be detrimental for consumer welfare. We know of no examples of such cases, however.

22. See Van de Ven and Jeurissen (2005) for an assessment which makes moral duties for firms a function of the competitiveness of the context.

23. See Commission Guidelines on the applicability of Article 81 EC to horizontal cooperation agreements, paragraph 280. See also generally Judgment of 12 May 2010, EMC Development Case, T-432/05, ECLI:EU:T:2010:189.

24. As pointed out in note 16, competition law may even prohibit agreements where firms do not pass on the higher costs to consumers, but let them fall on other stakeholders such as employees' wages or shareholders' dividends. This is because even a potential negative impact may be labelled as sufficiently deleterious to competition to be caught by the prohibition.

25. Generally, there is no competition law risk, though in certain circumstances (in the EU) Member States may infringe specific judge-made prohibitions of European competition law which states that it is prohibited to stimulate cartels, or rubber stamp cartels by using legislation (see also below).

26. Many interfirm agreements are the result of NGO's pressure or a government's push towards self regulation. This, however, makes them of an even more hybrid nature, especially when NGO's or the government are not merely giving a push, but are actively involved, as sometimes happens, in negotiating the agreement.

27. See our argument in Claassen and Gerbrandy (2016) and further references therein.

28. Analogous to privatized welfare state services, firms volunteering to protect public interests provide a case study in public/private hybridization. The development originates at the other (i.e., private) side of the public/private divide, but the effect is the same: governance by private agents in the public interest. Both developments intersect where the privatization of formerly public services makes them become subject to competition law (Prosser 2005a, 2005b). 
29. For overviews, see Heath, Moriarty, and Norman (2010); Néron (2010); Scherer and Palazzo (2011); and Whelan (2012).

30. We recognize that this makes our position conditional on Ciepley's (and others') adherence to one of several competing theories of the corporation. Often three main ones are distinguished (sometimes under different names): the artificial or fictional view, the real entity view, and the aggregate view (related to the nexus of contracts view) of the corporation. For one overview and further references, see Avi-Yonah (2005). While our conclusions are probably fundamentally antithetical to the aggregate view, it may however, be possible to reach similar conclusions on the real entity view.

31. Of course some single actions by large firms may have large, coercive effects on society as a whole. We need not exclude this possibility categorically, but neither should we accept a categorical demand for legitimation of all single actions by corporations.

32. To avoid misunderstandings: the direct object of our inquiry - the object of demands of political legitimacy -is 'interfirm agreements' (i.e., actions undertaken by corporations). However, such agreements do not take place in a political vacuum. Hence, what is simultaneously at stake is the legitimacy of competition law, when it is prohibiting or allowing such agreements. This is one and the same enquiry (in the same way in which the legitimacy of selling drugs and the legitimacy of the law prohibiting or allowing this are one and the same topic).

33. The Competition Authority considered whether there would be sufficient residual competition in the market as a result of the arrangements, as is required under the Dutch Competition Act, and concluded that whilst alternative products from poulterers, butchers, and market traders were available, they did not constitute sufficient residual competition. See Netherlands Authority for Consumers and Markets, ACM's Analysis of the Sustainability Arrangements Concerning the 'Chicken of Tomorrow' ACM/DM/2014/206028, page 8.

34. On this concept see for example the European Commission notice on the relevant market, OJ C 372 of 9 December 1997: http://eur-lex.europa.eu/legal-content/EN/TXT/?uri=celex:31997Y1209(01).

35. The safe harbour for this type of agreement lies fairly low, at $15 \%$ of the relevant market. In most agreements discussed above, the market share of the parties was considerably higher. Furthermore, the exception clause (of Article 101 par, 3 TFEU), also includes the requirement that the agreement, which is then accepted as limiting competition by (for example) leading to a higher price, leaves residual competition on the market. This, for the reasons stated above, is a difficult requirement to square with the idea that the interfirm agreement should cover most of the market.

36. Note that on this criterion the coercive effects of single actions of dominant firms using and abusing their market power may also be subject to legitimation demands.

37. We do not engage here with the literature on political CSR, in which democratization of firm decision making is an important topic. A further exploration on the similarities between our model and that literature could be useful. See Scherer and Palazzo $(2007,2011)$ and the discussion in Hussain and Moriarty (2018).

38. The Guidelines of the European Commission on article 101 (3) TFEU state that "all efficiency claims must be substantiated" (point 51 of the Guidelines). Though our plea is to not limit the beneficial claims to economic efficiencies, the substantiation requirement must of course remain.

39. For the press release see: http://europa.eu/rapid/press-release_IP-11-473_en.htm.

40. Judgment of 18 July 2013, Consiglio nazionale dei geologi and Autorità Garante della Concorrenza e del mercato v Autorità Garante della Concorrenza e del mercato and Consiglio nazionale dei geologi, C-136/12, ECLI:EU:C:2013:489.

41. See: https://mneguidelines.oecd.org/globalforumonresponsiblebusinessconduct/GFRBC2015Summary-Report.pdf.

42. The Australian Competition and Consumer Act, for example, contains an express provision to grant authorization "in the public interest." This concept has been accepted to encompass "anything of value to the community generally" (Tribunal in the 1976 QCMA decision). In South Africa, public interest provisions are also expressly included in the country's competition law.

43. The claim that this is a swamp of "of subjective reasoning" (see quote above) is a well known first-year law student objection to balancing. For a discussion aimed at these first-year students see: http:// lsolum.typepad.com/legaltheory/2014/12/legal-theory-lexicon-balancing-tests.html.

44. A competition law self assessment for firms is standard practice, though in our model the self assessment would include a substantiation of positive effects on the public interests aimed to protect. For an example of this in the area of the human rights impacts of corporate action, see Harrison (2013). We thank one of the reviewers for this reference. 


\section{REFERENCES}

Abizadeh, Arash. 2007. "Cooperation, Pervasive Impact, and Coercion: On the Scope (Not Site) of Distributive Justice." Philosophy \& Public Affairs 35 (4): 318-58.

Avi-Yonah, Reuven S. 2005. "The Cyclical Transformations of the Corporate Form: A Historical Perspective on Corporate Social Responsibility." Delaware Journal of Corporate Law. 30: 767-818.

Baarsma, Barbara. 2011. "Rewriting European Competition Law from an Economic Perspective.” European Competition Journal 7 (3): 559-85.

Balleisen, Edward. 2009. "The Prospects for Effective "Co-Regulation in the United States: An Historian's View from the Early Twenty-First Century." In Government and Markets: Toward a New Theory of Regulation, edited by Edward Balleisen and David Moss, 443-81. New York: Cambridge University Press.

Balleisen, Edward, and Marc Eisner. 2009. "The Promise and Pitfalls of Co-Regulation: How Governments Can Draw on Private Governance for Public Purpose." In New Perspectives on Regulation, edited by David Moss and John Cisternino, 127-50. Cambridge, MA: The Tobin Project.

Benn, Stanley, and Gerald Gaus. 1983. "The Liberal Conception of the Public and the Private." In Public and Private in Social Life, edited by Stanley Benn and Gerald Gaus, 31-65. London: Croom Helm.

Blanc, Sandrine. 2016. "Are Rawlsian Considerations of Corporate Governance Illiberal? A Reply to Singer." Business Ethics Quarterly 26 (3): 407-21.

Bork, Robert. 1978. The Antitrust Paradox: A Policy at War with Itself. New York: Free Press.

Bos, Jacqueline. 2002. "Antitrust Treatment of Cartels: A Comparative Survey of Competition Law Exemptions in the United States, the European Union, Australia and Japan." Global Studies Law Review 1 (1-2): 415-450.

Brock, James W. 1983. "Structural Monopoly, Technological Performance and Predatory Innovation: Relevant Standards under Section 2 of the Sherman Act." American Business Law Journal 21: 291-306

Buchanan, Allen, and Robert Keohane. 2006. "The Legitimacy of Global Governance Institutions." Ethics \& International Affairs 20 (4): 405-37.

Budzinski, Oliver. 2008. "Monoculture versus Diversity in Competition Economics." Cambridge Journal of Economics 32 (2): 295-324.

Ciepley, David. 2013. "Beyond Public and Private: Toward a Political Theory of the Corporation.” American Political Science Review 107 (1): 139-58.

Claassen, Rutger, and Anna Gerbrandy. 2016. "Rethinking Competition Law: From a Consumer Welfare to a Capability Approach." Utrecht Law Review 12 (1): 1-15.

Coglianese, Cary, and Evan Mendelson. 2010. "Meta-Regulation and Self-Regulation." In The Oxford Handbook of Regulation, edited by Robert Baldwin, Martin Cave, and Martin Lodge, 146-68. Oxford: Oxford University Press.

Cseres, Kati. 2007. "The Controversies of the Consumer Welfare Standard." The Competition Law Review 3 (2): 121-73.

Davies, William. 2010. "Economics and the 'Nonsense' of Law: The Case of the Chicago Antitrust Revolution." Economy and Society 39 (1): 64-83.

De Vries, Sybe A. 2013. "Balancing Fundamental Rights with Economic Freedoms According to the European Court of Justice." Utrecht Law Review 9 (1): 169-192.

Dubbink, Wim, and Frans Paul Van der Putten. 2008. "Is Competition Law an Impediment to CSR?" Journal of Business Ethics 83: 381-95. 
Gerber, David, 2001. Law and Competition in Twentieth-Century Europe: Protecting Prometheus. Oxford: Oxford University Press.

Gerbrandy, Anna. 2015. "Addressing the Legitimacy Problem for Competition Authorities Taking into Account Non-Economic Values. The Position of the Dutch Competition Authority." European Law Review, no. 5, 769-81.

. 2017. "Solving a Sustainability-Deficit in European Competition Law." World Competition 40 (4): 539-62.

Harrison, James. 2013. "Establishing a meaningful human rights due diligence process for corporations: learning from experience of human rights impact assessment." Impact Assessment and Project Appraisal, 31 (2): 107-117.

Heath, Joseph, Jeffrey Moriarty, and Wayne Norman. 2010. "Business Ethics and (or as) Political Philosophy.” Business Ethics Quarterly 20 (3): 427-52.

Herzog, Lisa. 2017. "No Company Is an Island. Sector-Related Responsibilities as Elements of Corporate Social Responsibility." Journal of Business Ethics 146 (1): 135-148.

Hussain, Waheed, and Jeffrey Moriarty. 2018. "Accountable to Whom? Rethinking the Role of Corporations in Political CSR." Journal of Business Ethics 149 (3): 519-534.

Jenny, Frederic. 2016. "The Institutional Design of Competition Authorities: Debates and Trends." In Competition Law Enforcement in the BRICS and Developing Countries, edited by Frederic Jenny and Yannis Katsoulacos, 1-58. Switzerland: Springer.

Kaplow, Louis. 2012. "On the Choice of Welfare Standards in Competition Law.” In The Goals of Competition Law, edited by Daniel Zimmer, 3-26. Cheltenham, UK: Edward Elgar.

Kerber, Wolfgang. 2007. "Should Competition Law Promote Efficiency? Some Reflections of an Economist on the Normative Foundations of Competition Law." In Economic Theory and Competition Law, edited by Josef Drexl, Laurence Idot, and Joel Moneger, 93-120. Cheltenham, UK: Edward Elgar.

Kingston, Suzanne. 2010. "Integrating Environmental Protection and EU Competition Law: Why Competition Isn't Special." European Law Journal 16: 780-805.

Klatt, Matthias, and Moritz Meister. 2012. The Constitutional Structure of Proportionality. Oxford: Oxford University Press.

Lianos, Ioannis. 2013. "Some Reflections on the Question of the Goals of EU Competition Law". CLES Working Article Series 3. London: UCL Faculty of Laws:

Loozen, Edith. 2015. "De Onwenselijkheid van de Beleidsregel Mededinging En Duurzaamheid." Economisch-Statistische Berichten 100 (4723-4724): 708-12.

McMahon, Christopher. 2012. Public Capitalism. The Political Authority of Corporate Executives. Philadelphia: University of Pennsylvania Press.

Monti, Giorgio. 2013. "EU Competition Law from Rome to Lisbon: Social Market Economy." In Aims and Values in Competition Law, edited by Caroline HeideJørgensen, Christian Bergqvist, Ulla Neergard, and Sune Troels Poulsen, 27-66. Copenhagen: DJØF Publishing.

. 2002. "Article 81 EC and Public Policy." Common Market Law Review 39: 1057-99.

Mulder, Jotte. 2016. Social Legitimacy in the Internal Market - a Dialogue of Mutual Responsiveness (PhD Thesis). Florence: European University Institute.

Néron, Pierre-Yves. 2010. "Business and the Polis: What Does It Mean to See Corporations as Political Actors?" Journal of Business Ethics 94 (3): 333-52.

Odudu, Okeoghene. 2010. "The Wider Concerns of Competition Law." Oxford Journal of Legal Studies 30 (3): 599-613. 
Parret, Laura. 2010. “Shouldn’t We Know What We are Protecting - Yes We Should - A Plea for a Solid and Comprehensive Debate about the Objectives of EU Competition Law and Policy" European Competition Journal 6 (3): 339-376.

Pera, Alberto. 2008. "Changing View of Competition, Economic Analysis and EC Antitrust Law." European Competition Journal 4 (1): 127-68.

Peter, Fabienne. 2010. "Political Legitimacy." Stanford Encyclopedia of Philosophy.

Poli, Eleanora. 2015. Antitrust Institutions and Policies in the Globalising Economy.

New York: Palgrave Macmillan

Prosser, Tony. 2005a. "Competition Law and Public Services: From Single Market to Citizenship Rights?" European Public Law 11 (4): 543-63.

- 2005b. The Limits of Competition Law. Markets and Public Services. Oxford: Oxford University Press.

Rawls, John. 1999. A Theory of Justice. Revised. Oxford: Oxford University Press.

Ripstein, Arthur. 2004. "Authority and Coercion.” Philosophy \& Public Affairs 32 (1): 2-35.

Scott, Inara. 2016. "Antitrust and Socially Responsible Collaboration: A Chilling Combination?" American Business Law Journal 53: 97-144.

Scherer, Andreas, and Guido Palazzo. 2007. "Toward A Political Conception of Corporate Responsibility: Business and Society Seen From A Habermasian Perspective." Academy of Management Review 32 (4): 1096-1120.

- 2011. "The New Political Role of Business in a Globalized World: A Review of a New Perspective on CSR and Its Implications for the Firm, Governance, and Democracy." Journal of Management Studies 48 (4): 899-931.

Schmitz, Stefan. 2002. The European Commission's Decision in GE/Honeywell and the Question of the Goals of Antitrust Law. University of Pennsylvania Journal of International Economic Law 23: 539-595.

Singer, Abraham. 2015. "There Is No Rawlsian Theory of Corporate Governance.” Business Ethics Quarterly 25 (1): 65-92. . 2017. "The Corporation as a Relational Entity." Polity 49 (3): 328-51.

Stark, Andrew. 2010. Drawing the Line. Public and Private in America. Washington D.C.: The Brookings Institution.

Stucke, Maurice E. 2012. Reconsidering Antitrust's Goals. Boston College Law Review 53 (2): 551-629.

Townley, Christopher. 2008. "Is Anything More Important than Consumer Welfare (in Article 81 ERC)? Reflections of a Community Lawyer." Cambridge Yearbook of European Legal Studies 10: 345-81.

Van de Ven, Bert, and Ronald Jeurissen. 2005. "Competing Responsibly." Business Ethics Quarterly 15 (2): 299-317.

Weintraub, Jeff. 1997. "The Theory and Politics of the Public/Private Distinction." In Public and Private in Thought and Practice, edited by Jeff Weintraub and Krishan Kumur, 1-42. Chicago \& London: The University of Chicago Press.

Wempe, Johan. 2009. "Industry and Chain Responsibilities and Integrated Social Contracts Theory." Journal of Business Ethics 88: 751-64.

Whelan, Glen. 2012. "The Political Perspective of Corporate Social Responsibility: A Critical Research Agenda.” Business Ethics Quarterly 22 (4): 709-37.

Witt, Anne C. 2012. "Public Policy Goals Under EU Competition Law: Now Is the Time to Set the House in Order." European Competition Journal 8 (3): 443-71.

Zimmer, Daniel, ed. 2012. The Goals of Competition Law. Cheltenham: Edward Elgar. 